\title{
Effects of 5-Hydroxytryptamine on Neuronal Activities in the Rat Dorsolateral Septal Nucleus
}

\author{
MASASHI GOTO \\ Department of Physiology, Kurume University School of Medicine, \\ Kurume 830-0011, Japan
}

\begin{abstract}
Summary: The ionic channels and signal transduction pathways underlying the 5-hydroxytryptamine (5-HT)-induced hyperpolarization in neurons of the rat dorsolateral septal nucleus (DLSN) were examined by using intracellular and voltage-clamp recording techniques. Application of 5 - $\mathrm{HT}$ $(1-50 \mu \mathrm{M})$ caused a hyperpolarizing response associated with a decreased membrane resistance in DLSN neurons. The hyperpolarization induced by $5-\mathrm{HT}$ was blocked by $\mathrm{Ba}^{2+}(1 \mathrm{mM})$ but not by tetraethylammonium (TEA, $3 \mathrm{mM})$, glibenclamide $(100 \mu \mathrm{M})$ and extracellular $\mathrm{Cs}^{+}(2 \mathrm{mM})$. 8-Hydroxydi-n-propylamino tetralin (8-OH-DPAT; $3 \mu \mathrm{M}$ ), a selective agonist for the $5-\mathrm{HT}_{1 \mathrm{~A}}$ receptor, mimicked $5-\mathrm{HT}$ in producing the hyperpolarization. The 5-HT hyperpolarization was blocked by NAN-190 $(5 \mu \mathrm{M})$, a $5-\mathrm{HT}_{1 \mathrm{~A}}$ receptor antagonist. CP93129 $(100 \mu \mathrm{M})$, a 5-HT ${ }_{1 \mathrm{~B}}$ receptor agonist, and L-694-247 $(100 \mu \mathrm{M})$, a $5-\mathrm{HT}_{1 \mathrm{~B} / 1 \mathrm{D}}$ receptor agonist, also produced hyperpolarizing responses. The order of agonist potency was 8-OH-DPAT $\gg$ CP93129 $\geq$ L-694-247. ( \pm )-2,5-Dimethoxy-4-iodoamphetamine hydrochloride (DOI, $100 \mu \mathrm{M})$, a $5-\mathrm{HT}_{2}$ receptor agonist, and $\mathrm{RS} 67333(100 \mu \mathrm{M})$, a $5-\mathrm{HT}_{4}$ receptor agonist, caused no hyperpolarizing response. The voltage-clamp study showed that 5-HT caused an outward current $\left(I_{5-\mathrm{HT}}\right)$ in a concentration-dependent manner. $\mathrm{I}_{5-\mathrm{HT}}$ was associated with an increased membrane conductance. $\mathrm{I}_{5-\mathrm{HT}}$ reversed the polarity at the equilibrium potential for $\mathrm{K}^{+}$ calculated by the Nernst equation. $\left.\right|_{5-\mathrm{HT}}$ showed inward rectification at membrane potentials more negative than $-70 \mathrm{mV}$. Ba ${ }^{2+}(100 \mu \mathrm{M})$ blocked the inward rectifier $\mathrm{K}^{+}$current induced by $5-\mathrm{HT}$. $\mathrm{I}_{5-\mathrm{HT}}$ was irreversibly depressed by intracellular application of guanosine 5'-O-(3-thiotriphosphate)(GTP$\gamma \mathrm{S})$ but not by guanosine 5'-O-(2-thiodiphosphate) (GDP $\beta S$ ). These results suggest that in rat DLSN neurons activation of $5-\mathrm{HT}_{1 \mathrm{~A}}$ receptors causes a hyperpolarizing response by activating mainly the inward rectifier $\mathrm{K}^{+}$channels through a GTP-binding protein.
\end{abstract}

Key words lateral septum, 5-HT, hyperpolarization, 5- $\mathrm{HT}_{1 \mathrm{~A}}$ receptors, G-protein, GIRK channel, outward rectifier $\mathrm{K}^{+}$channel

\section{INTRODUCTION}

The lateral septum is the largest nuclear mass of the septal area which is known to be an integrated part of the limbic system in the rat brain. The principal neurons in the lateral septum receive a major neuronal projection from hippocampal CA1 and CA3 neurons and in turn send efferents to hypothalamic and amygdaloid areas [1-4]. The lateral septal neurons also receive serotonergic input from medial and dorsal raphe nuclei $[5,6]$. In vitro autoradiography has demonstrated that 5-hydroxytryptamine (5-HT) receptors, especially $5-\mathrm{HT}_{1 \mathrm{~A}}$ receptors, are localized with the highest density in the lateral septum and the hippocampus [7-11]. Molecular cloning has established that $5-\mathrm{HT}_{1 \mathrm{~A}}$ receptors belong to the superfamily of GTP binding protein (G-protein)-coupled receptor [12-16]. A family of cDNA cloning subunits of the pertussis toxin (PTX)-sensitive G-protein activates the inward rectifier $\mathrm{K}^{+}$(GIRK) channels in neuronal cells $[17,18]$. Coexistence with the rat brain GIRK3 and other subunits in Xenopus oocytes give 
rise to prominent current which is enhanced by stimulation of co-expressed 5- $\mathrm{HT}_{1 \mathrm{~A}}$ receptors [19]. Sim et al. [20] have demonstrated high level of 5$\mathrm{HT}_{1 \mathrm{~A}}$-stimulated $\left.{ }^{35} \mathrm{~S}\right] \mathrm{GTP} \gamma \mathrm{S}$ binding in the lateral septum. In situ hybridization revealed a substantial distribution of GIRK1-4 mRNA in the rat lateral septum [21]. Electrophysiological studies have shown that 5-HT produces hyperpolarizing responses in neurons of the dorsolateral septal nucleus (DLSN) [22-24]. The purpose of the present study is to examine the properties of the $\mathrm{K}^{+}$channels and signal transduction system underlying the 5-HT-induced hyperpolarization in DLSN neurons.

\section{MATERIALS AND METHODS}

Coronal slices containing the lateral septal nucleus were obtained from the rat brain in a manner described previously [25]. Male Wistar rats, 80-150 $\mathrm{g}$, were killed by decapitation and their brains were rapidly removed and immersed for $8-10 \mathrm{~s}$ in a cooled artificial cerebrospinal fluid (ACSF $4-6^{\circ} \mathrm{C}$ ) that was pre-bubbled with $95 \% \mathrm{O}_{2}-5 \% \mathrm{CO}_{2}$. Transverse slices ( $500 \mu \mathrm{m}$ in thickness) were cut with a Vibroslice (Campden Instruments) and left to recover for one hour in oxygenated ACSF at room temperature (22$24^{\circ} \mathrm{C}$ ). The slice was then transferred to a chamber and submerged in ACSF at $32-33{ }^{\circ} \mathrm{C}$. The composition of the ACSF was as follows (in $\mathrm{mM}$ ): $\mathrm{NaCl}$, $117 ; \mathrm{KCl}, 4.7 ; \mathrm{CaCl}_{2}, 2.5 ; \mathrm{MgCl}_{2}, 1.2 ; \mathrm{NaHCO}_{3}, 25$; $\mathrm{NaH}_{2} \mathrm{PO}_{4}, 1.2$ and d-glucose, 11 (pH 7.4 and 295-305 mOsm). Recording of the membrane potential of DLSN neurons was made with a microelectrode filled with $3 \mathrm{M} \mathrm{K}$-acetate. The tip resistance of microelectrodes was $100-140 \mathrm{M} \Omega$. Under voltageclamp, membrane currents were obtained with an Axoclamp-2A amplifier using discontinuous single electrode voltage clamp (dSEVC) mode at a sampling rate of $2-5 \mathrm{kHz}$ and gain of $0.8 \mathrm{nA} / \mathrm{mV}$. The head stage output was continuously monitored. The current-voltage (I-V) relationship was obtained by applying a ramp command potential from holding potentials of $-75 \mathrm{mV}$ to $-140 \mathrm{mV}$ to $-40 \mathrm{mV}$ and back to the holding potentials at a rate of approximately $0.2 \mathrm{~V} / \mathrm{s}$. The membrane voltage and current were monitored continuously with a pen-writing recorder and memory oscilloscope (Nihon-Kohden, RTA-1100). The pClamp software program (Axon Instruments) operating on an IBM-AX computer (Gateway 2000) was used to analyze the membrane currents. All drugs except glibenclamide were dissolved in the Krebs solution. Glibenclamide and
L-694-247 were dissolved in DMSO and added to the Krebs solution, where the final concentration of DMSO was $0.1 \%$ which had no direct effect on DLSN neurons. Of the drugs used, 5-HT creatinine phosphate, guanosine 5'-O-(3-thiotriphosphate)(GTP$\gamma \mathrm{S})$, guanosine 5'-O-(2-thiodiphosphate) (GDP $\beta \mathrm{S}$ ), NAN-190 and glibenclamide were purchased from Sigma (St Louis, MO). Tetrodotoxin (TTX) and tetraethylammonium chloride were purchased from Wako Pure Chemical Industries, Ltd. ( \pm )-2,5-Dimethoxy-4-iodoamphetamine hydrochloride (DOI) and 8-hydroxy-di-n-propylamino tetralin (8-OH-DPAT) were purchased from RBI (Natick, MA). RS67333, CP93129 and L-694-247 were from TOCRIS. All experiments were carried out at a temperature of 30$32{ }^{\circ} \mathrm{C}$. Each experimental value is presented as the mean \pm SE (standard error of the mean) and was analyzed by Student's $t$-test.

\section{RESULTS}

\section{Effects of 5-HT on membrane properties of DLSN neurons}

Neurons in the rat DLSN had a resting membrane potential of $-70 \pm 3 \mathrm{mV}(\mathrm{n}=45)$ and input resistance of $132 \pm 11 \mathrm{M} \Omega(\mathrm{n}=45)$. Bath-application of 5-HT (10 $\mu \mathrm{M})$ caused a hyperpolarizing response with amplitude of $14 \pm 3 \mathrm{mV}$ in 76 neurons $(84 \%)$ out of 91 neurons (an example is shown in Fig. 1). The remaining $5(6 \%)$ neurons showed no obvious changes in the resting membrane potential during the application of $5-\mathrm{HT}$. The rate of firing of spontaneous action potentials was markedly reduced during the 5-HT hyperpolarization. Voltage-current relationship (V-I) curve was constructed by application of rectangular current pulses with a duration of $300 \mathrm{msec}$ (Fig. 1B). 5 -HT $(100 \mu \mathrm{M})$ decreased the slope of the V-I curve, suggesting a decreased input resistance (Fig. 1C). The 5-HT hyperpolarization reversed polarity at $-82 \mathrm{mV}$ in this particular neuron (Fig. 1C). The reversal potential obtained from 7 neurons was $-96 \pm 6 \mathrm{mV}$.

\section{Effects of 5-HT receptor agonist and antagonist in DLSN neurons}

8-OH-DPAT $(3 \mu \mathrm{M})$, a selective agonist for the $5-\mathrm{HT}_{1 \mathrm{~A}}$ receptor [26-32], produced a hyperpolarizing response associated with a decreased membrane resistance (Fig. 2A). It has been shown that NAN190 is a relatively selective antagonist for the $5-\mathrm{HT}_{1 \mathrm{~A}}$ receptor [29]. NAN-190 $(10 \mu \mathrm{M})$ produced no significant change in the membrane potential in DLSN 
A
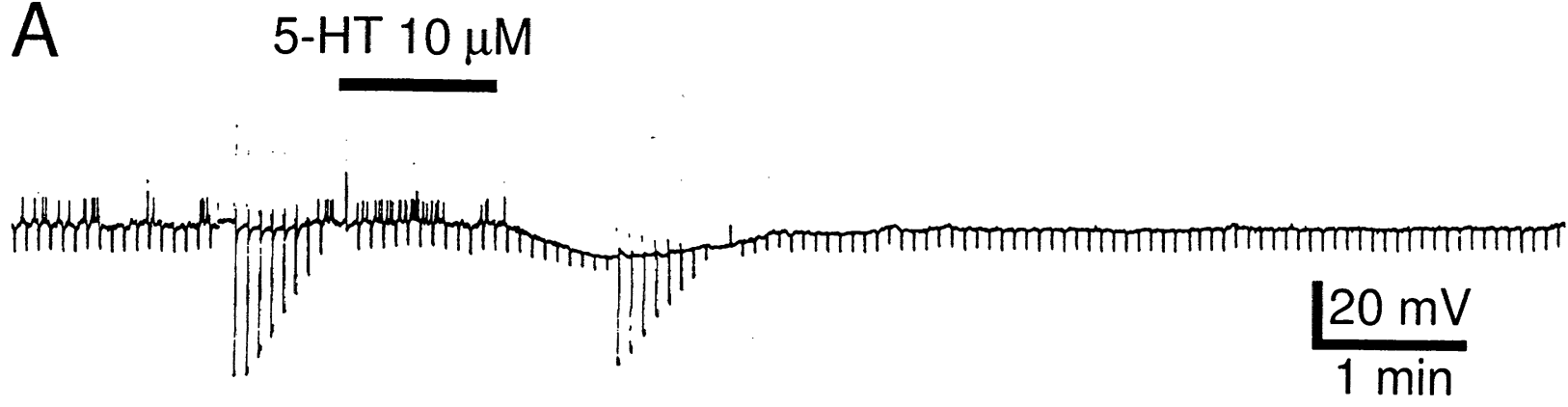

B

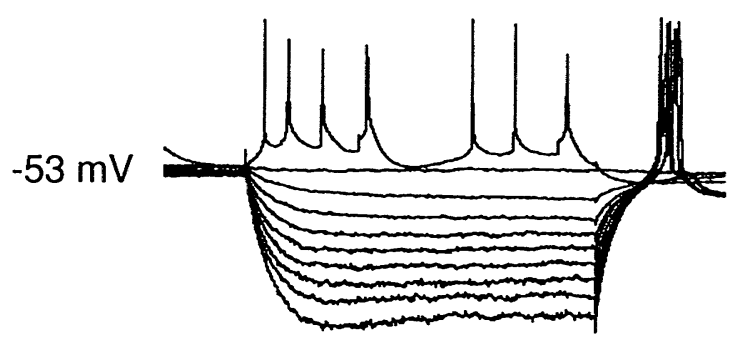

$-63 \mathrm{mV}$
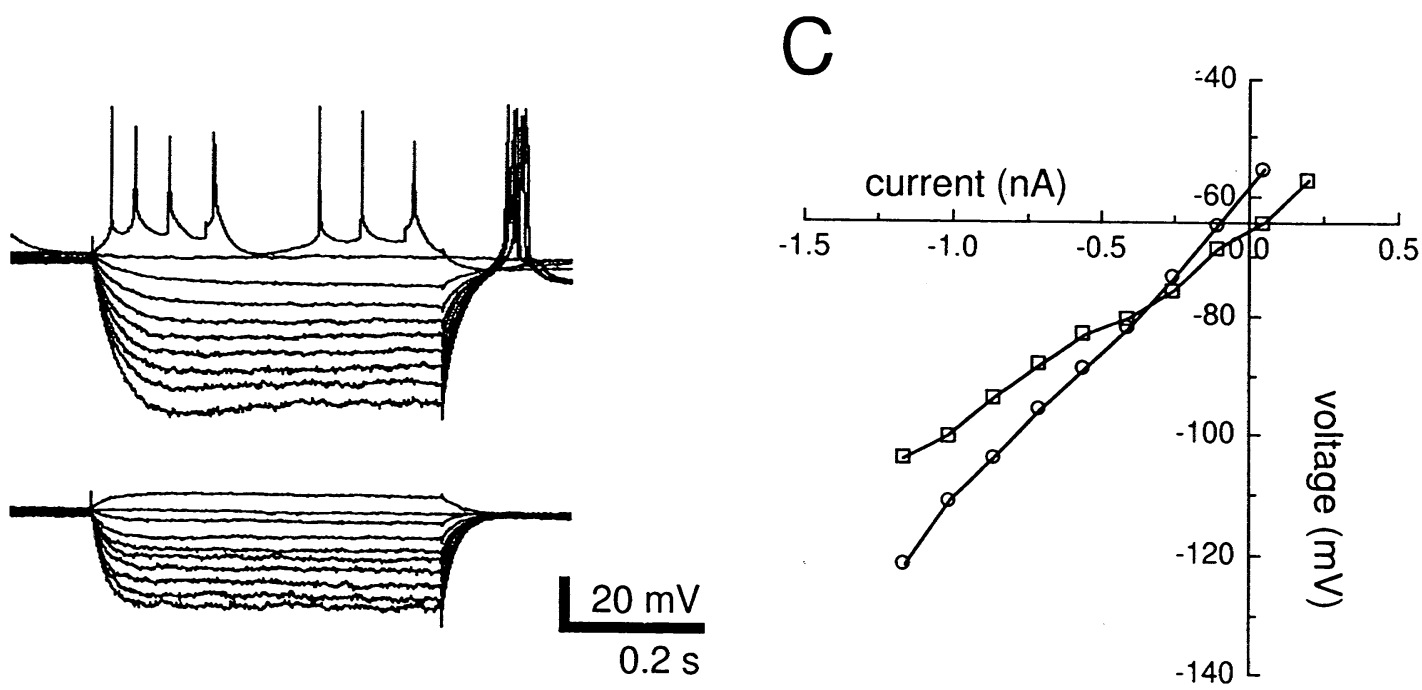

Fig. 1. Effect of 5-HT on passive membrane properties of DLSN neurons. A: a pen-writer recording of 5-HTinduced hyperpolarization in a DLSN neuron. A horizontal bar indicates the period of bath-application of 5-HT $(10 \mu \mathrm{M})$. Downward deflections indicate electrotonic potentials produced by application of cathodal current pulses with duration of $500 \mathrm{~ms}$. Upward deflections indicate spontaneous action potentials. B: expanded records of electrotonic potentials produced by injection of anodal and cathodal current pulses with duration of $500 \mathrm{~ms}$. C: voltage-current relationship obtained before $(\bigcirc)$ and during application of 5-HT $(\square)$. All data were obtained from records (A).

TABLE 1.

Effects of 5-HT-receptor agonists and antagonists on rat septal neurons

\begin{tabular}{|c|c|c|}
\hline Agonists and antagonist & receptor type & hyperpolarizations \\
\hline \multicolumn{3}{|l|}{ Agonists } \\
\hline$(10 \mu \mathrm{M})$ & - & $14 \pm 3 \mathrm{mV}(\mathrm{n}=8)$ \\
\hline 8-OH-DPAT $(3 \mu \mathrm{M})$ & $5-\mathrm{HT}_{1 \mathrm{~A}}$ & $7 \pm 3 \mathrm{mV}(\mathrm{n}=6)$ \\
\hline \multirow[t]{2}{*}{ CP93129 } & $5-\mathrm{HT}_{1 \mathrm{~B}}$ & no effect \\
\hline & - & $11 \mathrm{mV}(\mathrm{n}=1)$ \\
\hline \multirow[t]{2}{*}{ L-694-247 } & $5-\mathrm{HT}_{1 \mathrm{D} / \mathrm{1B}}$ & no effect \\
\hline & - & $8 \pm 3 \mathrm{mV}(\mathrm{n}=3)$ \\
\hline$(100 \mu \mathrm{M})$ & $5-\mathrm{HT}_{2}$ & no effect \\
\hline$(100 \mu \mathrm{M})$ & $5-\mathrm{HT}_{4}$ & no effect \\
\hline \multicolumn{3}{|l|}{ Antagonist } \\
\hline NAN-190 & $5-\mathrm{HT}_{1 \mathrm{~A}}$ & block \\
\hline
\end{tabular}

8-OH-DPAT: 8-hydroxy-di-n-propylamino tetralin; DOI: ( \pm )-2,5-Dimethoxy-4iodoamphetamine hydrochloride 
A

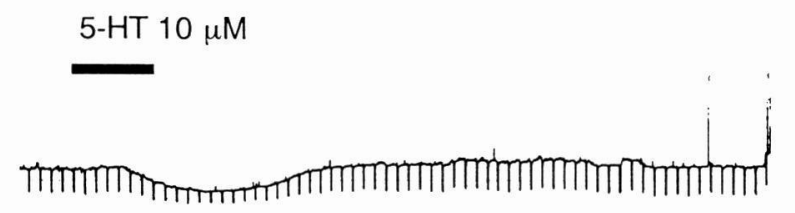

8-OH-DPAT $3 \mu \mathrm{M}$



B

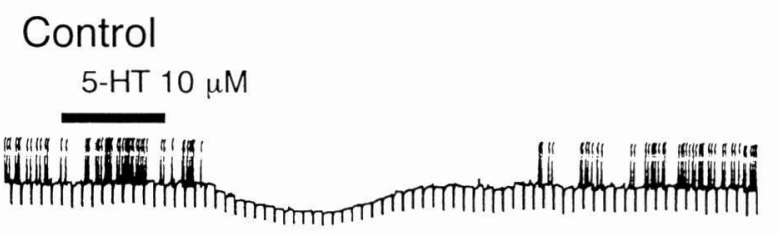

NAN-190 $10 \mu \mathrm{M}$

5-HT $10 \mu \mathrm{M}$

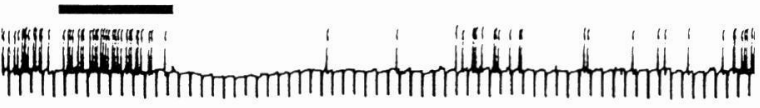

$20 \mathrm{mV}$

$1 \mathrm{~min}$

Fig. 2. Effects of an agonist (A) and an antagonist (B) for 5-HT receptors on DLSN neurons. A: effects of 8-OH-DPAT $(3 \mu \mathrm{M})$ and 5-HT $(10 \mu \mathrm{M})$ on the same neuron. The drugs were applied to the ACSF during the period indicated by horizontal bars. B:blockade of the 5HT-induced hyperpolarization by NAN-190. The 5-HT hyperpolarizations were recorded in the absence (top) and presence (bottom) of NAN-190 $(10 \mu \mathrm{M})$. The horizontal bars indicate the period of application of 5-HT.

neurons. The hyperpolarization induced by $5-\mathrm{HT}(10$ $\mu \mathrm{M})$ was blocked by NAN-190 $(10 \mu \mathrm{M})$ (Fig. 2B). CP93129 $(10 \mu \mathrm{M})$, a $5-\mathrm{HT}_{1 \mathrm{~B}}$ receptor agonist $[33,34]$, and L-694-247 $(10 \mu \mathrm{M})$, a 5-HT $1 \mathrm{~B} / 1 \mathrm{D}$ receptor agonist [35], did not produce hyperpolarization in DLSN neurons. When the concentration was increased to $100 \mu \mathrm{M}$, CP93129 and L-694-247 produced hyperpolarization in DLSN neurons. The order of agonist potency was 8-OH-DPAT $\gg$ CP93129 $\geq$ L-694-247.
DOI $(100 \mu \mathrm{M})$, a $5-\mathrm{HT}_{2}$ receptor agonist $[30,36]$, produced no hyperpolarizing response in DLSN neurons. RS67333 $(100 \mu \mathrm{M})$, a $5-\mathrm{HT}_{4}$ receptor agonist [37], had no ability to hyperpolarize the DLSN neurons. These results are summarized in Table 1.

\section{Effects of channel blockers on the 5-HT hyper- polarization}

Tetraethylammonium (TEA, $3 \mathrm{mM}$ ), a blocker for the delayed rectifier $\mathrm{K}^{+}$current [38], did not depress the hyperpolarization induced by 5-HT (Fig. 3A). $\mathrm{Cs}^{+}(1 \mathrm{mM})$, a blocker for non-selective cation channels (Q-current, [39]), did not depress the hyperpolarization induced by 5-HT (Fig. 3B). $\mathrm{Ba}^{2+}$ has been known to block several $\mathrm{K}^{+}$currents in neuronal membrane [40-44]. The rate of spontaneous action potential was markedly increased in a ACSF containing $\mathrm{Ba}^{2+}(1 \mathrm{mM})$. The 5-HT hyperpolarization was depressed by $70 \pm 5 \%(\mathrm{n}=12)$ by $\mathrm{Ba}^{2+}$ (Fig. 3C). Glibenclamide $(100 \mu \mathrm{M})$, a blocker for the ATPsensitive $\mathrm{K}^{+}$channels $[45,46]$, did not block the 5-HT hyperpolarization (Fig. 3D). The 5-HT hyperpolarization of DLSN neurons was not depressed, when $\mathrm{Ca}^{2+}$ was removed from the ACSF. It is well known that intracellular $\mathrm{Cs}^{+}$blocks $\mathrm{K}^{+}$channels in a nonselective manner [47]. In the present study, $\mathrm{Cs}^{+}$was injected to DLSN neurons by applying outward DC current through intracellular microelectrode. $\mathrm{Cs}^{+}-$ treated DLSN neurons had an action potential with a prolonged plateau on the falling phase. The 5-HT hyperpolarization was reduced in DLSN neurons that had been injected by $\mathrm{Cs}^{+}$.

\section{5-HT-induced outward current in DLSN neurons}

Under voltage-clamp condition, 5-HT (1-50 $\mu \mathrm{M})$ caused an outward current $\left(\mathrm{I}_{5-\mathrm{HT}}\right)$ in DLSN neurons (Fig. 4A). A current-voltage relationship (I-V curve) was constructed using a ramp command potential that held the membrane potential at values from -140 to $-40 \mathrm{mV}$ (Fig. $4 \mathrm{~B})$. TTX $(1 \mu \mathrm{M})$ was added to the ACSF to block the action potential. 5-HT increased the slope of the I-V curve at all holding membrane potentials, indicating an increased membrane conductance during $\mathrm{I}_{5 \text {-нт. }}$. The effect of 5-HT in producing the outward current in DLSN neurons was concentration-dependent (Fig. 4C). The minimum effective concentration of 5 -HT was $1 \mu \mathrm{M}$. This concentration produced the outward current with amplitude of approximately $10 \mathrm{pA}$. At a concentration of $50 \mu \mathrm{M}, 5-\mathrm{HT}$ caused the maximum response with amplitude of $230 \pm 18 \mathrm{pA}(\mathrm{n}=6)$. The half-maximum response $\left(\mathrm{EC}_{50}\right)$ of $\mathrm{I}_{5-\mathrm{HT}}$ was produced by $2 \mu \mathrm{M} 5-\mathrm{HT}$. 


\section{A Control}


C Control

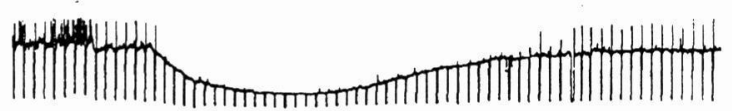

D Control

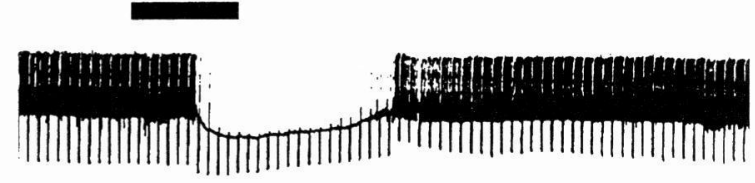

TEA (3 mM)


$\mathrm{BaCl}_{2}(1 \mathrm{mM})$
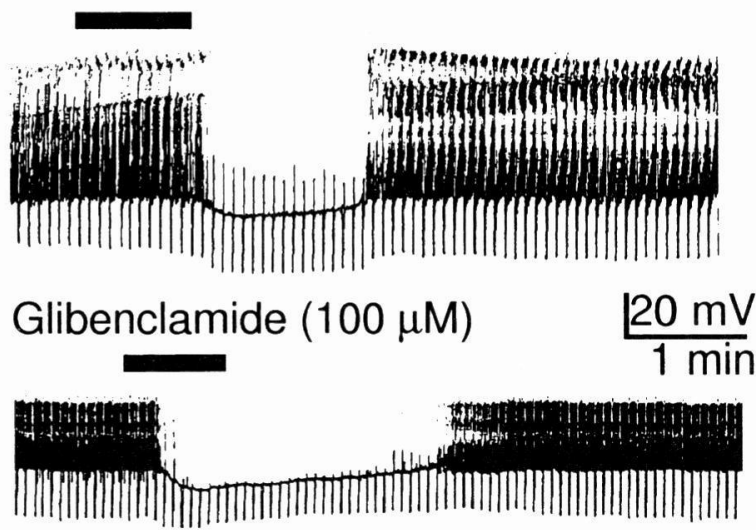

Fig. 3. Effect of $\mathrm{K}^{+}$-channel blockers (TEA, $\mathrm{CsCl}, \mathrm{BaCl}_{2}$ and glibenclamide) on the 5-HT hyperpolarizations. Horizontal bars indicate the period of bath-application of 5-HT. Each blocker was applied to the bath $5-10 \mathrm{~min}$ before application of 5-HT. Note that $\mathrm{Ba}^{2+}(1 \mathrm{mM})$ depressed the 5-HT hyperpolarization.

$\mathrm{I}_{5-\mathrm{HT}}$ was recorded at several membrane potentials (Fig. 5A). When DLSN neurons were hyperpolarized, $\mathrm{I}_{5-\mathrm{HT}}$ decreased in amplitude and finally reversed the polarity. In 7 neurons, the reversal potential of $\mathrm{I}_{5-\mathrm{HT}}$ was $-90 \pm 4 \mathrm{mV}$ in the normal ACSF (containing $4.7 \mathrm{mM} \mathrm{K}^{+}$). The reversal potential of $\mathrm{I}_{5 \text {-HT }}$ was also recorded from DLSN neurons superfused with an external solution containing 1 , 9.7 or $20 \mathrm{mM} \mathrm{K}^{+}$(Fig. 5B). The reversal potential was shifted to $-125 \pm 3 \mathrm{mM}(\mathrm{n}=5),-72 \pm 2 \mathrm{mM}(\mathrm{n}=6)$ and $-42 \pm 2 \mathrm{mM}(\mathrm{n}=7)$ in 1,10 and $20 \mathrm{mM} \mathrm{K}^{+}$solution, respectively. Figure $5 \mathrm{C}$ shows the relationship between the reversal potential of $\mathrm{I}_{5-\mathrm{HT}}$ and the concentration of extracellular $\mathrm{K}^{+}$. The slope of this curve was $54 \mathrm{mV}$, suggesting that $\mathrm{I}_{5-\mathrm{HT}}$ reversed polarity at the equilibrium potential for $\mathrm{K}^{+}$calculated by the Nernst equation. Interestingly, the $\mathrm{K}^{+}$conductance which links to 5-HT receptors seems voltage-dependent, because $\mathrm{I}_{5-\mathrm{HT}}$ increased in amplitude at hyperpolarizing membrane potentials in high $\mathrm{K}^{+}$solutions (Fig. 5B).

The properties of the 5 -HT-activated $\mathrm{K}^{+}$channels in DLSN neurons were examined by using the I-V curve. In the absence of 5-HT, an almost linear I-V curve was produced by the ramp command potential in DLSN neurons. In contrast, the 5-HT-induced membrane conductance was markedly increased at potentials more negative than $-70 \mathrm{mV}$ (Fig. 6A). The net $\mathrm{I}_{5 \text {-HT }}$ was obtained by subtraction of the control I$\mathrm{V}$ curve from that recorded during the application of 
A

$$
\text { 5-HT } 10 \mu \mathrm{M}
$$


Fig. 4. Outward currents produced by 5-HT in DLSN neurons. A: a pen-writing record of 5-HTinduced outward current $\left(\mathrm{I}_{5-\mathrm{HT}}\right)$ in a DLSN neuron. Membrane conductance was measured by ramp command potentials before, during and after application of 5-HT. B: current-voltage relationship obtained before and during the application of 5-HT $(10 \mu \mathrm{M})$. These curves are based on the data shown in record (A). C: concentration-response relationship of 5-HT obtained from 4-11 neurons for each point. Vertical lines indicate the SE of the mean. The data were fitted to a modified Michaelis-Menten equation by using the least-squares fitting: $I=\left(I_{\max } \cdot C^{n}\right) /\left(C^{n}+E_{50}{ }^{n}\right)$, where I was the drug-induced current, $I_{\max }$ was the maximum response, $\mathrm{C}$ was the concentration of $5-\mathrm{HT}, \mathrm{EC}_{50}{ }^{\mathrm{n}}$ was the concentration that produced the halfmaximum response and $\mathrm{n}$ was the Hill coefficient.

5-HT. The net $\mathrm{I}_{5 \text {-HT }}$ showed a marked inward rectification in $45 \%$ of the neurons (Fig. $6 \mathrm{~B}$ ). In the remaining $55 \%$ of the neurons, $\mathrm{I}_{5-\mathrm{HT}}$ was less sensitive to the membrane potential (Figs 6C and D). $\mathrm{Ba}^{2+}$, at the relatively low concentration of $100-200 \mu \mathrm{M}$, has been reported to selectively block the inward rectifier $\mathrm{K}^{+}$current in central neurons [48]. In DLSN neurons $\mathrm{Ba}^{2+}(100 \mu \mathrm{M})$ depressed the inward rectifier $\mathrm{I}_{5 \text {-HT }}$ (Fig. 7). These results suggest that 5-HT hyperpolarizes the DLSN neurons by activating the inward rectifier $\mathrm{K}^{+}$currents.

\section{Contribution of G-protein to $I_{5-H T}$}

GTP $\gamma \mathrm{S}(10 \mathrm{mM})$ was applied to the intracellular space by diffusion from an intracellular microelectrode. 5-HT $(10 \mu \mathrm{M})$ was applied to the superfusing solution $5 \mathrm{~min}$ after insertion of the microelectrode. 5-HT produced a hyperpolarization that did not recover. The membrane potential was continuously shifted to a hyperpolarizing potential, even when 5HT was removed from the superfusing solution, probably because of diffusion of GTP $\gamma \mathrm{S}$ into the 



Fig. 5. Reversal potentials of $\mathrm{I}_{5-\mathrm{HT}}$. A: $\mathrm{I}_{5-\mathrm{HT}}$ was recorded at various holding potentials. The neuron was held at two different potentials by using hyperpolarizing voltage commands. Holding potentials are shown at the left of records. B: the relationships between the amplitude of $\mathrm{I}_{5-\mathrm{HT}}$ and the holding voltage. $\mathrm{I}_{5-\mathrm{HT}}$ was obtained in the presence of $1.0(\triangle), 4.7(\square), 9.7(\bigcirc)$ or $20(\square) \mathrm{mM} \mathrm{K} \mathrm{K}^{+}$. Lines were fitted by eye. C: reversal potentials of $\mathrm{I}_{5 \text {-нт }}$ plotted against the concentration of external $\mathrm{K}^{+}$. Each point is the mean of data from 4-6 cells. Vertical lines represent SE of mean.

intracellular space. Further repeated applications of 5 -HT at intervals of $20 \mathrm{~min}$ caused no hyperpolarization (Figs $7 \mathrm{~A}$ and $\mathrm{C}$ ). GDP $\beta \mathrm{S}(3 \mathrm{mM})$ was also applied to the intracellular space of DLSN neurons by diffusion from an intracellular microelectrode. However, the 5-HT hyperpolarization was not depressed by injection GDP $\beta$ S in DLSN neurons for more than $50 \mathrm{~min}$ (Figs 7B and D).

\section{DISCUSSION}

The present study showed that 5-HT caused a hyperpolarizing response, associated with increased membrane conductance, in DLSN neurons. 8-OHDPAT $(3 \mu \mathrm{M})$, a $5-\mathrm{HT}_{1 \mathrm{~A}}$ receptor agonist, also produced a hyperpolarizing response in DLSN neurons. Although CP93129 and L-694-247, 5-HT $1 \mathrm{~B} / 1 \mathrm{D}$ agonists, also produced hyperpolarizing responses, these drugs were less potent than 5-HT. Agonists for the 5$\mathrm{HT}_{2}$ receptor, DOI $(100 \mu \mathrm{M})$ and the $5-\mathrm{HT}_{4}$ receptor agonist, RS67333 $(100 \mu \mathrm{M})$ caused no hyperpolarizing response in DLSN neurons. The hyperpolarization induced by 5 -HT $(10 \mu \mathrm{M})$ was almost completely depressed by NAN-190 $(500 \mathrm{nM})$, an antago- 


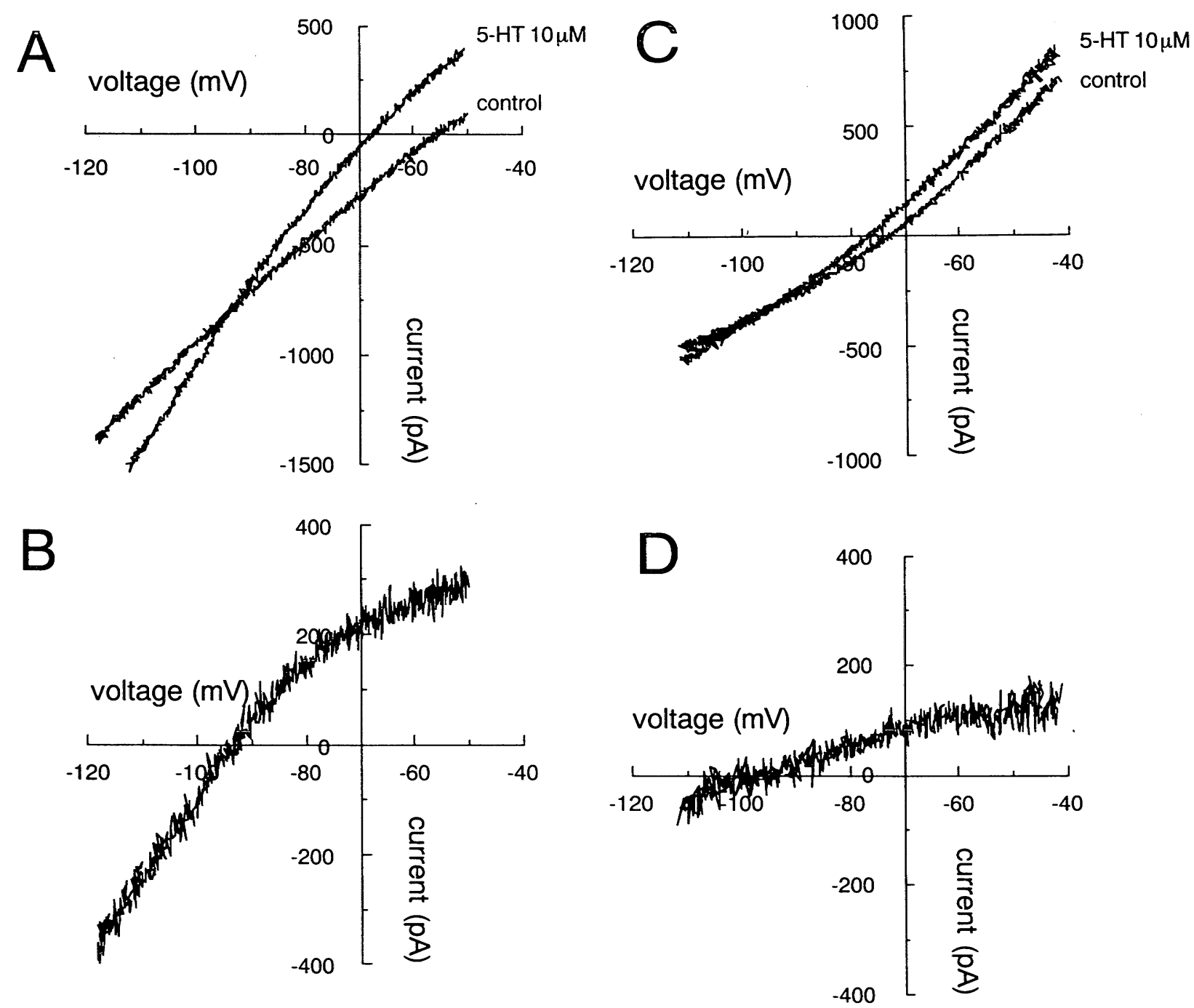

Fig. 6. Current-voltage relationships (I-V curves) from two different DLSN neurons (A, B and C, D) constructed using ramp command potentials. The membrane potential was initially held at $-70 \mathrm{mV}$. A: I-V curves were taken in the absence (control) and presence of $5-\mathrm{HT}(10 \mu \mathrm{M})$. B: net $\mathrm{I}_{5-\mathrm{HT}}$ obtained by subtraction of the I-V curve for 5-HT from the control curve in (A). C: I-V curves were obtained in the absence and presence of 5-HT $(10 \mu \mathrm{M})$. D: net $\mathrm{I}_{5-\mathrm{HT}}$ calculated for the curves shown in $\mathrm{C}$.

nist for the $5-\mathrm{HT}_{1 \mathrm{~A}}$ receptor subtype. These results suggest that the $5-\mathrm{HT}_{1 \mathrm{~A}}$ receptors are mainly responsible for the hyperpolarization in neurons of the DLSN.

Under voltage-clamp condition, 5-HT (1-50 $\mu \mathrm{M})$ caused an outward current $\left(\mathrm{I}_{5-\mathrm{HT}}\right)$ associated with an increased membrane conductance. $\mathrm{I}_{5-\mathrm{HT}}$ reversed polarity at the equilibrium potential for $\mathrm{K}^{+}$calculated by the Nernst equation. Intracellular $\mathrm{Cs}^{+}$has been known to block $\mathrm{K}^{+}$channels in a non-selective manner [47]. Injection of $\mathrm{Cs}^{+}$in the intracellular space of DLSN neurons depressed the 5-HT hyperpolarization. The 5-HT hyperpolarization was not blocked by extracellular $\mathrm{Cs}^{+}$, a blocker for nonselective cation channels that are activated at hyperpolarizing membrane potentials (Q-current, [39]). The delayed rectifier $\mathrm{K}^{+}$channel and ATPsensitive $\mathrm{K}^{+}$channels may not be responsible for the 



Fig. 7. Effect of $\mathrm{Ba}^{2+}(100 \mu \mathrm{M})$ on the membrane current of a DLSN neuron. A: the 5-HT-induced inward rectifier $\mathrm{K}^{+}$current was obtained from I-V curves taken before and during the application 5-HT $(10 \mu \mathrm{M})$. B: the 5-HT-induced current in the presence of $\mathrm{Ba}^{2+}$. Note that $\mathrm{Ba}^{2+}$ depressed not only the amplitude of $\mathrm{I}_{5-\mathrm{HT}}$ but also inward rectifier properties.

5-HT hyperpolarization, because TEA and glibenclamide did not block the 5-HT hyperpolarization. $\mathrm{Ca}^{2+}$-activated $\mathrm{K}^{+}$current does not seem to be involved in the current underlying the 5-HT hyperpolarization, because the outward current induced by 5-HT was not blocked by removal of $\mathrm{Ca}^{2+}$ from either the external or internal solution $[24,44]$. In DLSN neurons, the net $\mathrm{I}_{5 \text {-HT }}$ showed inward rectifi- cation at potentials more negative than $-70 \mathrm{mV} . \mathrm{Ba}^{2+}$ $(100 \mu \mathrm{M})$, known to be a blocker for the inward rectifier $\mathrm{K}^{+}$current [48], depressed the inward rectifier $\mathrm{K}^{+}$ current produced by $5-\mathrm{HT}$.

$\mathrm{I}_{5-\mathrm{HT}}$ was irreversibly reduced by intracellular injection of GTP $\gamma \mathrm{S}$ but not by GDP $\beta$ S in DLSN neurons. Several studies have reported that $5-\mathrm{HT}_{1 \mathrm{~A}}$ receptors are coupled to the inward rectifier $\mathrm{K}^{+}$ channels through a G-protein in neurons of the dorsal raphe nucleus $[40,43,44]$. Interestingly, injection of GDP $\beta$ S into the cells produced no or relatively weak inhibition of $\mathrm{I}_{5-\mathrm{HT}}$ in neurons of the hippocampus and the dorsal raphe nucleus $[44,49]$. Katayama et al. [44] have reported that 5- $\mathrm{HT}_{1 \mathrm{~A}}$ receptors are coupled to a G-protein which is resistant to GDP $\beta$ S. The Gprotein which mediates $\mathrm{I}_{5 \text {-HT }}$ in DLSN neurons may belong to a GDP $\beta$ S-resistant type. Previous reports have suggested that the G-protein coupled to the 5HT receptor is PTX-sensitive (Gi and/or Go) in dorsal raphe nucleus neurons [40,41,50]. Further experiments are needed, however, to clarify whether a PTX-sensitive G-protein is involved in the 5-HT $1 \mathrm{~A}$ receptor-mediated activation of the inward rectifier $\mathrm{K}^{+}$current in rat DLSN neurons.

As an integrated part of the limbic system, the septum plays an important role in the control of a variety of physiological and behavioral processes related to higher cognitive functions, emotions and stress, as well as autonomic regulation. It is of particular interest that the $5-\mathrm{HT}_{1 \mathrm{~A}}$ receptor has been implicated in depression, anxiety and panic disorder [26-28,30-32,51]. The principal neurons in the lateral septum receive a massive hippocampo-septal projection which contains axons of CA1 and CA3 pyramidal neurons, and in turn send efferents to the hypothalamic and amygdaloid area [1-4]. The principal neurons in the lateral septum contain $\gamma$-aminobutyric acid (GABA) and participate in local inhibitory circuits within the lateral septum, via their axon collaterals [3]. Stimulation of GABAergic neurons in the lateral septum evoked inhibitory postsynaptic potentials (IPSPs) [52]. The present study showed that 5-HT completely depressed the spontaneous firing activity of principal neurons in the lateral septum. The inhibition of GABAergic neurons may lead to disinhibition of excitatory synaptic transmission in the lateral septum. Supporting this hypothesis, 5-HT has been reported to depress the IPSPs in DLSN neurons [24]. An extracellular study has shown that the excitatory component of the field potentials in the lateral septum evoked by electrical stimulation of fimbrial fibers, was increased by 


\section{A}

\section{control}

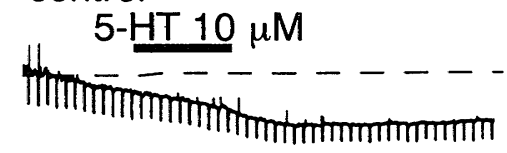

B

control

5- $\underline{\mathrm{HT}} 10 \mu \mathrm{M}$

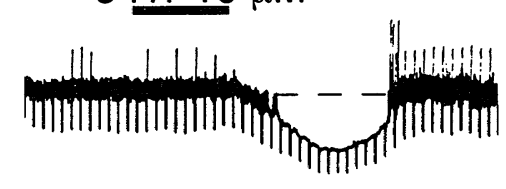

$10 \mathrm{~min}$



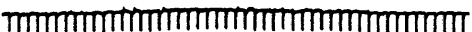

$20 \min$

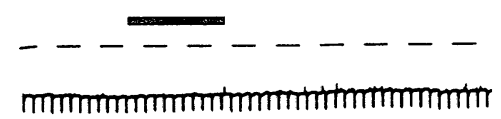

$10 \min$



$40 \min$

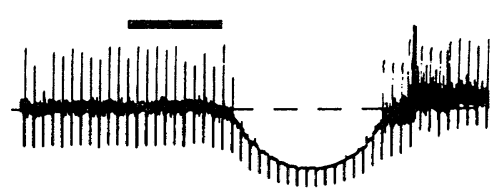

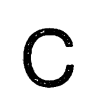

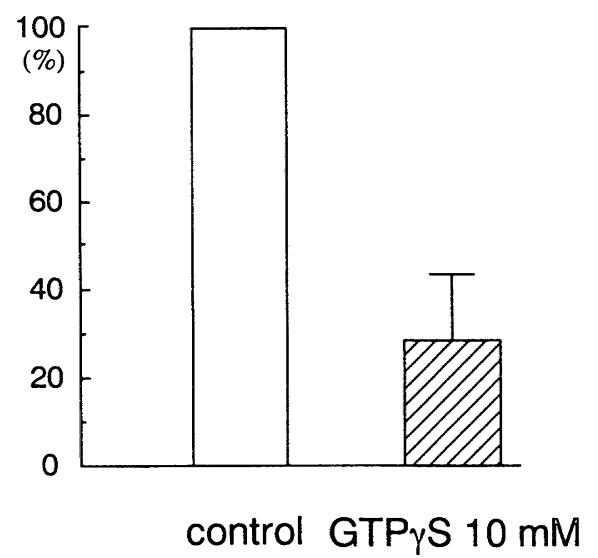

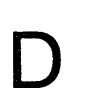

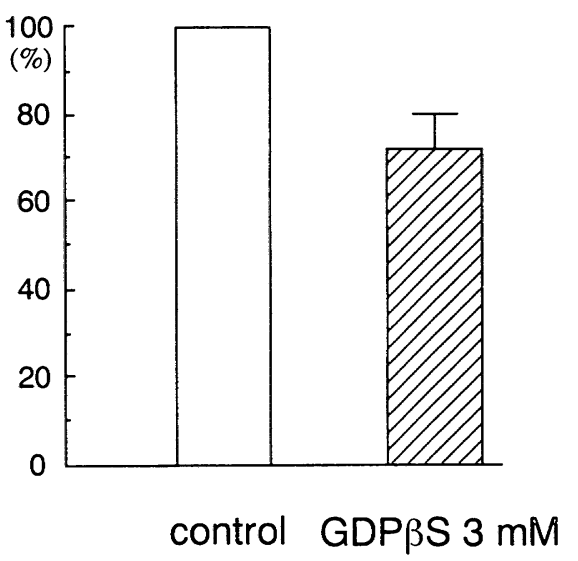

Fig. 8. Effects of GTP $\gamma \mathrm{S}(10 \mathrm{mM})$ and GDP $\beta \mathrm{S}(3 \mathrm{mM})$ on the 5-HT hyperpolarization obtained from two different DLSN neurons. A and B: sample records of the 5-HT hyperpolarizations obtained from neurons treated with GTP $\gamma \mathrm{S}(\mathrm{A})$ and GDP $\beta \mathrm{S}$ (B). 5-HT hyperpolarizations were recorded 5, 10 and 20-40 min after insertion of the microelectrode. $C$ and D: ordinate indicates the amplitude of the 5-HT hyperpolarization. The 5-HT hyperpolarization recorded $5 \mathrm{~min}$ after insertion of the microelectrode is taken as control $(100 \%)$.

ionophoretic application of $5-\mathrm{HT}$, whereas the inhibitory component was diminished [53]. Recently, we also observed that 5-HT enhanced the excitatory postsynaptic potential (EPSP) in the DLSN (unpublished observation). These reports, together with the present study, suggest that serotonergic neurons facilitate excitatory synaptic transmission in the hippocampus-septum pathway by depressing the GABAergic inhibitory circuit.

ACKNOWLEDGMENTS: I am most grateful to Professors K. Oizumi and T. Akasu for their useful suggestion and continuous encouragement during the present study. The author also thanks Drs. H. Hasuo and M. Tsurusaki for their helpful comments. This work was supported by The Ishibashi Research Fund and a Grant-in-Aid for Scientific Research from the Ministry of Education, Science, Sports and Culture of Japan.

\section{REFERENCES}

1. Joëls M, and Urban IJA. Electrophysiological and pharmacological evidence in favor of amino acid neurotransmission in fimbria-fornix fibers innervating the lateral septal complex of rats. Exp Brain Res 1984; 54:455-462.

2. Alonso JR, and Frotscher M. Organization of the septal region in the rat brain: A Golgi/EM study of lateral septal neurons. J Comp Neurol 1989; 286:472-487.

3. Jakab RL, and Leranth C. Inhibitory lateral septumhypothalamus pathway. A PHA-L tracing/GABA-immunogold EM study. Soc Neurosci Abstr 1992; 18:917. 
Jakab RL, and Leranth C. Septum. In: The Rat Nervous 4. System, 2nd edn., ed. Paxinos G, Academic Press, San Diego, pp 405-442, 1995.

Köhler C, Chan-Palay V, and Steinbusch H. The

5. distribution and origin of serotonin-containing fibers in the septal area: A combined immunohistochemical and fluorescent retrograde tracing study in the rat. $\mathbf{J}$ Comp Neurol 1982; 209:91-111.

Gall C, and Moore RY. Distribution of enkephalin,

6. substance $P$, tyrosine hydroxylase, and 5-hydroxytryptamine immunoreactivity in the septal region of the rat. J Comp Neurol 1984; 225:212-227.

Biegon A, Rainbow TC, and McEwen BS. Quantitative

7. autoradiography of serotonin receptors in the rat brain. Brain Res 1982; 242:197-204.

Marcinkiewicz M, Verge D, Gozlan H, Pichat L, and

8. Hamon M. Autoradiographic evidence for the heterogeneity of $5-\mathrm{HT}_{1}$ sites in the rat brain. Brain Res 1984; 291:159-163.

Pazos A, and Palacios JM. Quantitative autoradiographic

9. mapping of serotonin receptors in the rat brain. I. Serotonin-1 receptors. Brain Res 1985; 346:205-230.

Vergé D, Daval G, Marcinkiewicz M, Patey A, El

10. Mestikawy $S$ et al. Quantitative autoradiography of multiple $5-\mathrm{HT}_{1}$ receptor subtypes in the brain of control or 5,7-dihydroxytryptamine-treated rats. J Neurosci 1986; 6:3474-3482.

Hensler JG, Kovachich GB, and Frazer A. A quantitative

11. autoradiographic study of $\operatorname{serotonin}_{1 \mathrm{~A}}$ receptor regulation. Effect of 5,7-dihydroxytryptamine and antidepressant treatments. Neuropsychopharmacology 1991; 4:131-144. Fargin A, Raymond JR, Lohse MJ, Kobilka BK, Caron

12. MG et al. The genomic clone G-21 which resembles a $\beta$ adrenergic receptor sequence encodes the $5-\mathrm{HT}_{1 \mathrm{~A}}$ receptor. Nature 1988; 335:358-360.

Albert PR, Zhou Q-Y, Van Tol HHM, Bunzow JR, and

13. Civelli $\mathrm{O}$. Cloning, functional expression, and mRNA tissue distribution of the rat 5-hydroxytryptamine ${ }_{1 \mathrm{~A}}$ receptor gene. J Biol Chem 1990; 265:5825-5832.

Peroutka SJ. 5-Hydroxytryptamine receptors. In:

14. Handbook of Receptors and Channels: G ProteinCoupled Receptors, ed. Peroutka SJ, CRC Press, Boca Raton, Vol 1, pp 209-236, 1994.

Peroutka SJ. Molecular biology of serotonin (5-HT)

15. receptors. Synapse 1994; 18:241-260.

Peroutka SJ, and Howell TA. The molecular evolution of

16. G protein-coupled receptors: focus on 5-hydroxytryptamine receptors. Neuropharmacology 1994; 33:319-324.

Dascal N, Schreibmayer W, Lim NF, Wang W, Chavkin

17. $\mathrm{C}$ et al. Atrial $\mathrm{G}$ protein-activated $\mathrm{K}^{+}$channel: expression cloning and molecular properties. Proc Natl Acad Sci USA 1993; 90:10235-10239.

Kubo Y, Reuveny E, Slesinger PA, Jan YN, and Jan LY.

18. Primary structure and functional expression of a rat Gprotein-coupled muscarinic potassium channel. Nature $1993 ; 364: 802-806$

Di $\beta$ mann E, Wischmeyer E, Spauschus A, Pfeil DV,

19. Karschin $\mathrm{C}$ et al. Functional expression and cellular mRNA localization of a $\mathrm{G}$ protein-activated $\mathrm{K}^{+}$inward rectifier isolated from rat brain. Biochem Biophys Res
Commun 1996; 223:474-479.

Sim LJ, Xiao R, and Childers SR. In vitro autoradio-

20. graphic localization of $5-\mathrm{HT}_{1 \mathrm{~A}}$ receptor-activated Gproteins in the rat brain. Brain Res Bull 1997; 44:39-45.

Karschin C, Di $\beta$ mann E, Stühmer W, and Karschin A.

21. IRK(1-3) and GIRK(1-4) inwardly rectifying $\mathrm{K}^{+}$channel mRNAs are differentially expressed in the adult rat brain. J Neurosci 1996; 16:3559-3570.

Joëls M, Twery MJ, Shinnick-Gallagher P, and

22. Gallagher JP. Multiple actions of serotonin on lateral septal neurons in rat brain. Eur J Pharmacol 1986; 129:203-204.

Joëls M, Shinnick-Gallagher P, and Gallagher JP. Effect

23. of serotonin and serotonin analogues on passive membrane properties of lateral septal neurons in vitro. Brain Res 1987; 417:99-107.

Joëls M, and Gallagher JP. Actions of serotonin recorded

24. intracellularly in rat dorsal lateral septal neurons. Synapse 1988; 2:45-53.

Stevens DR, Gallagher JP, and Shinnick-Gallagher P.

25. Intracellular recordings from rat dorsolateral septal neurons, in vitro. Brain Res 1984; 305:353-356.

Engel JA, Hjorth S, Svensson K, Carlsson A, and

26. Liljequist $\mathrm{S}$. Anticonflict effect of the putative serotonin receptor agonist 8-hydroxy-2-(di-n-propylamino)tetralin (8-OH-DPAT). Eur J Pharmacol 1984; 105:365-368.

Cervo L, and Samanin R. Potential antidepressant

27. properties of 8-hydroxy-2-(di-n-propylamino)tetralin, a selective serotonin $_{1 \mathrm{~A}}$ receptor agonist. Eur J Pharmacol $1987 ; 144: 223-229$.

Kennett GA, Dourish CT, and Curzon G. Antidepressant-

28. like action of $5-\mathrm{HT}_{1 \mathrm{~A}}$ agonists and conventional antidepressants in an animal model of depression. Eur $\mathbf{J}$ Pharmacol 1987; 134:265-274.

Fletcher A, Cliffe IA, and Dourish CT. Silent 5-HT AA $_{1}$

29. receptor antagonists: utility as research tools and therapeutic agents. TiPS 1993; 14:441-448.

Kennett GA. 5- $\mathrm{HT}_{1 \mathrm{C}}$ receptors and their therapeutic

30. relevance. Curr Opin Invest Drugs 1993; 2:317-362.

Schreiber R, and De Vry J. 5- $\mathrm{HT}_{1 \mathrm{~A}}$ receptor ligands in

31. animal models of anxiety, impulsivity and depression: multiple mechanisms of action? Prog Neuropsychopharmacol Biol Psychiatry 1993; 17:87-104.

Detke MJ, Wieland S, and Lucki I. Blockade of the

32. antidepressant-like effects of 8-OH-DPAT, buspirone and desipramine in the rat forced swim test by $5 \mathrm{HT}_{1 \mathrm{~A}}$ receptor antagonists. Psychopharmacology 1995; 119:4754.

Koe BK, Nielsen JA, Macor JE, and Heym J.

33. Biochemical and behavioral studies of the $5-\mathrm{HT}_{1 \mathrm{~B}}$ receptor agonist, CP-94,253. Drug Dev Res 1992; 26:241-250.

Yu X-J, Waeber C, Castanon N, Scearce K, Hen R et al.

34. 5-Carboxamido-tryptamine, CP-122,288 and dihydroergotamine but not sumatriptan, CP-93,129, and serotonin5-O-carboxymethyl-glycyl-tyrosinamide block dural plasma protein extravasation in knockout mice that lack 5-hydroxytryptamine ${ }_{1 \mathrm{~B}}$ receptors. Mol Pharmacol 1996; 49:761-765.

Glennon RA, Hong S-S, Bondarev M, Law H, Dukat M 
35. et al. Binding of $O$-alkyl derivatives of serotonin at human 5-HT1D $\beta$ receptors. J Med Chem 1996; 39:314322.

Baxter G, Kennett G, Blaney F, and Blackburn T. 5-HT

36. receptor subtypes: a family re-united? TiPS 1995; 16:105-110.

Eglen RM, Bonhaus DW, Johnson LG, Leung E, and

37. Clark RD. Pharmacological characterization of two novel and potent $5-\mathrm{HT}_{4}$ receptor agonists, RS 67333 and $\mathrm{RS}$ 67506 , in vitro and in vivo. $\mathrm{Br} \mathrm{J}$ Pharmacol 1995; 115:1387-1392.

Rudy B. Diversity and ubiquity of $\mathrm{K}$ channels.

38. Neuroscience 1988; 25:729-749.

Halliwell JV, and Adams PR. Voltage-clamp analysis of

39. muscarinic excitation in hippocampal neurons. Brain Res 1982; 250:71-92.

Innis RB, Nestler EJ, and Aghajanian GK. Evidence for

40. $G$ protein mediation of serotonin- and $G A B A_{B}$-induced hyperpolarization of rat dorsal raphe neurons. Brain Res 1988; 459:27-36.

Williams JT, Colmers WF, and Pan ZZ. Voltage- and

41. ligand-activated inwardly rectifying currents in dorsal raphe neurons in vitro. J Neurosci 1988; 8:3499-3506.

Brown DA. G-proteins and potassium currents in

42. neurons. Annu Rev Physiol 1990; 52:215-242.

Penington NJ, Kelly JS, and Fox AP. Whole-cell

43. recordings of inwardly rectifying $\mathrm{K}^{+}$currents activated by $5-\mathrm{HT}_{1 \mathrm{~A}}$ receptors on dorsal raphe neurones of the adult rat. J Physiol (Lond) 1993; 469:387-405.

Katayama J, Yakushiji T, and Akaike N. Characteriza-

44. tion of the $\mathrm{K}^{+}$current mediated by $5-\mathrm{HT}_{1 \mathrm{~A}}$ receptor in the acutely dissociated rat dorsal raphe neurons. Brain Res 1997; 745:283-292.

Sturgess NC, Ashford MLJ, Cook DL, and Hales CN.

45. The sulphonylurea receptor may be an ATP-sensitive potassium channel. Lancet 1985; 8453:474-475.

Schmid-Antomarchi H, De Weille J, Fosset M, and

46. Lazdunski $M$. The receptor for antidiabetic sulfonylureas controls the activity of the ATP-modulated $\mathrm{K}^{+}$channel in insulin-secreting cells. J Biol Chem 1987; 262:1584015844.

Hille B. Ionic Channels of Excitable Membranes, 2nd

47. edn. Sinauer, Sunderland, 1992.

North RA. Drug receptors and the inhibition of nerve

48. cells. Br J Pharmacol 1989; 98:13-28.

Andrade R, Malenka RC, and Nicoll RA. A G protein

49. couples serotonin and $\mathrm{GABA}_{B}$ receptors to the same channels in hippocampus. Science 1986; 234:1261-1265. Bobker DH, and Williams JT. Serotonin augments the

50. cationic current $I_{h}$ in central neurons. Neuron 1989; 2:1535-1540.

Lesch KP, Wiesmann M, Hoh A, Müller T, Disselkamp-

51. Tietze $\mathrm{J}$ et al. 5-HT $\mathrm{T}_{1 \mathrm{~A}}$ receptor-effector system responsivity in panic disorder. Psychopharmacology 1992; 106:111-117.

Gallagher JP, Zheng F, Hasuo H, and Shinnick-Gallagher

52. P. Activities of neurons within the rat dorsolateral septal nucleus (DLSN). Prog Neurobiol 1995; 45:373-395.

DeFrance JF, Kitai ST, McCrea RA, Kocsis JD, and

53. Hatada K. Excitatory effects of 5-hydroxytryptamine in the hippocampal-septal circuit. Brain Res 1973; 58:245250 . 